\title{
The Effect of Teams Games Tournament (TGT) and Student Teams Achievement Divisions (STAD) Teaching Techniques on The Learning Outcome of Natural Science Subject
}

\author{
Mahdalena Permatasari $^{*}$, Dadang Kurnia ${ }^{*}$, R. Teti Rostikawati ${ }^{*}$ \\ ${ }^{*}$ Universitas Pakuan, Bogor, Indonesia \\ Corresponding Author: dadang.kurnia@unpak.ac.id
}

\begin{abstract}
The Effect of Teams Games Tournament (TGT) and Student Teams Achievement Divisions (STAD) Teaching Techniques on the Learning Outcome of Natural Science Subject to the students of fifth grade at V SDN Cijujung 03 Kecamatan Bogor. The research employs quasi experimental method and it shows that the average score of the class using TGT gets $7.4 \%$ with the $\mathrm{N}$-gain of 1.26 and the class using Student Teams Achievement Divisions gets 5.7\% with N-gain of 1.02. The T-tailed score < significance or $0.00<0.05$ or Ha is accepted. It can be inferred that there is a significant effect of using TGT and STAD on natural science subject of class 5 at SDN Cijujung 03 in the district of Bogor, the academic year of 20142015.
\end{abstract}

Keywords: Teams Games Tournament, Student Teams Achievement Divisions, Learning Outcome.

\section{INTRODUCTION}

Education is the most important factor and a top priority that requires serious attention from all parties, because education is a determinant of the nation's progress in the future. National goals and ideals, for the intellectual life of the nation is contained in the 1945 Constitution. The government together with the community continues to seek the development of education for the realization of an independent, superior and ready nation to face the globalization world (Suchyadi, 2017). The development of a country or a nation is influenced by the quality of education. Education itself is a planned and conscious effort to implement learning process and condition which are in accordance with the aim. What it means by the aim of education is being able to produce students who have the capability of actively developing their own potentials, having religious, social, emotional controls, self control, personality, intelligence, and good attitude. Education has to be handled seriously. The management of education has to do many efforts to get qualified education. In improving students' learning potential, teacher can optimize available learning resources. Since the general goal of education nowadays is to support us to function effectively in the globalization era. Therefore, education is a strategic facility in developing human resources.

Nowadays, the learning process has not applied the real educational goal. It can be seen from daily learning process which is monotonous and dominated by the teacher. The class atmosphere tends to center to the teacher. It decreases the opportunity for the students to be active and independent, so that the students become passive and individual, cannot build perception, lack of motivation, interest, and critical thinking.

If the condition is left unsolved, then teacher will always be the only source in the classroom, there is no information exchange, and concept mastery and learning outcome of natural science subject is low. If we want to be successful in the learning process, then the subject has to be related to the students' experience which is gained by seeing, saying, touching, trying, and thinking. In this condition, students are made fun and happy. One of the ways to make students happy is by teaching them using learning model to improve students learning outcome. There are so many teaching techniques that can be used for teaching natural science. Each of the technique has its strength and weakness, but not all of the techniques are applicable.

The teaching techniques of Teams Games Tournament and Student Teams Achievement Divisions are chosen in the research, because both of the techniques have their own strength and weaknesses. First, the strength of Teams Games Tournament can grow students' eager, responsibility, and cooperation among students. In the application, Teams Games Tournament has strength which is asking students to play together. At first, students learn by digging early knowledge, after that the students are asked to play a game which is answering questions raised by the teacher. The students are enthusiastic because they can get score when they are able to answer the questions. 
Second, the weakness of Teams Games Tournament can be seen from how the students answer the questions, usually, the students who keep answering the questions are those who are smart, while those who are not quite smart do not try to answer. However the not quite smart students can hear the answer from the smart students. Therefore, Teams Games Tournament is considered to be able to improve the learning outcome of natural science subject of the fifth grade students.

While Student Teams Achievement Divisions in its implementation also has its strength and weakness compared to Teams Games Tournament. Student Teams Achievement Divisions has strength of seing groups as the reference for the students' achievement on the material delivered. The group activities which are discussing and flooring opinion are considered to be able to give the same opportunity to the students in one group. The weakness of Student Teams Achievement Divisions can be seen when they are discussing. The students who are low achievers keep silent and not saying anthing when discussing. There is a tendency that the smart students lead them. It can impede the finishing of assignments. Therefore, Student Teams Achievement Divisions is considered to improve the learning outcome of natural science subject to the fifth grade students of SDN Cijujung 03.

Teams Games Tournament and Student Teams Achievement Divisions are teaching techniques relevant to the teaching of natural science subject. Natural science subject is a learning concept and is very related to human life.

The teaching of natural science has important role in learning process and the development of technology, since natural science subject has an aim of raising students' interest and understanding on the nature which have many facts that are not discovered. Therefore, the finding of the study can be used for daily activity.

The teaching techniques that can be used by teachers of natural science subjects are and STAD. Both of the techniques require students to have their own knowledge from what they understand and remember. By doing so, the activity of teaching learning process becomes more efficient, effective, and lively. The learning activities are centered to the students, the learning goal can also be achieved, and finally it can improve the learning outcome of natural science subject.

The above statement is in accordance with the result of the test conducted by the writer at SDN Cijujung 03. There are 28 students at the fifth grade of $\mathrm{B}$ class. From the learning result, it can be seen that there are 27 students who have not gotten the minimum score which is 75 . It means that there are $95 \%$ of the students who have not reached the minimum score.

From the problems above, the writer is interested to conduct a study with the title of, "The
Effect of Teams Games Tournament and Student Teams Achievement Divisions on the learning outcome of natural science". Hence, the causing factors of the problems are: (1) Is there any effect of learning technique on the teaching of natural science subject? (2) Is there any effect of using teaching technique on the learning outcome of natural science subject? (3) Is there any effect of the use of media on the learning outcome of natural science subject? (4) Is there any effect of students' activity on their learning outcome? and (5) Is there any effect of TGT and STAD on the leaning outcome of natural science subject?

The problems are limited into three variables: two variables are the treatments which are Teams Games Tournament and Student Teams Achievement Divisions. The third variable is the independent one which is learning outcome. The subject being investigated is natural science in the material of human digestion.

The statement of the problem is: Is there any effect of Teams Games Tournament and Student Teams Achievement Divisions on the learning outcome of natural science at SDN Cijujung 03 in the Subdistrict of Sukaraja, the district of Bogor in the year of 2014/2015?

Dimyati (2006) states that the learning outcome is the result of learning process. Students' activity in learning process and learning outcome are things that have double sides. From the side of the students, learning outcome is 'the level of mental development' to be better than before the study was conducted. From the side of the teacher, learning outcome is the time when the subject has been finished. Learning outcome is measured by the measurement of the teacher, school, and national levels. Kunandar (2008) says that learning outcome is an act of a learning indivisual. It is not only about language, but also construct intelligence and internalization inside the learning individual. Learning outcome is the patterns of actions, values, understandings, attitudes, appreciations, and skills (Suprijono, 2009). It is supported by Saefullah (2012) saying that learning outcome is the change of attitude gained by the students after experiencing learning activities.

From several opinions above, it can be synthesized that learning outcome is a picture of students' mastery to absorb the learning material of a basic competence after joining a learning process. To improve learning outcome, teacher can use teaching technique which is in accordance to the subject, material, and condition of the students.

However Slavin (2009) says that Teams Games Tournament uses academic tournaments and using quizzes and scoring system for individual improvement, where students compete with those of other teams. TGT is mostly combined with STAD, and also doing certain tournament in the structure of regular STAD. 
Trianto (2010) states that Teams Games Tournament students play games with other team members will have extra points for their team.

However Rusman (2010) says that Teams Games Tournament is a cooperative learning type which puts students into learning groups having 5 to 6 members who have the ability, different gender, or different race.

Based on the above opinion, it can be synthesized that Teams Games Tournament is a learning technique that applies the ability of playing in group and training the students' psychmotor to stimulate their thinking ability to understand material given by playing games and is able to produce change of attitude such as students' cognitive, affective, and psychomotors.

Slavin (2009) states that Student Teams Achievement Division is one of cooperative learning methods which is very simple and is a good start for teachers who want to apply cooperative learning.

Isjoni (2009) says that Student Teams Achievement Division is one of cooperative types emphasizing activities and interaction among students to motivate each other and to help one another in mastering the material for getting optimal achievement.

Rusman (2011:213) says that Student Teams Achievement Division (STAD) is one of cooperative learning method which is simple but accurate to teach exact materials like calculation, mathematics, the uase of language, mechanics, geography, mapping skill, and other scientific concepts.

Table 1. Pre test, post test, and N-gain of TGT class

\begin{tabular}{|l|c|c|c|c|}
\hline \multirow{2}{*}{$\begin{array}{c}\text { The Learning } \\
\text { Outcome } \\
\text { using TGT }\end{array}$} & \multicolumn{2}{|c|}{ Teams Games Tournament (TGT) Class } & \multirow{2}{*}{$\begin{array}{c}\text { The Category } \\
\text { of N_Gain }\end{array}$} \\
\cline { 2 - 4 } $\begin{array}{l}\text { Maximum } \\
\text { Score }\end{array}$ & 7,5 & 9,6 & - & - \\
\hline $\begin{array}{l}\text { Minimum } \\
\text { Score }\end{array}$ & 2,5 & 5,3 & - & - \\
\hline Mean & 5,2 & 7,4 & 1,26 & High \\
\hline Sd & 2,2 & 2,7 & - & - \\
\hline $\begin{array}{l}\text { The number of } \\
\text { students } \\
\text { having higher } \\
\text { score than the } \\
\text { average }\end{array}$ & 1 & 11 & - & - \\
\hline
\end{tabular}

Based on the above opinions, it can be synthesized that Student Teams Achievement Division is a learning model using small groups with 4-5 members of each group which are heterogenous and it is done by first of all stating the aim of the learning process, material delivery, grouping, quizesm and group appreciation.

\section{RESEARCH METHODS}

The study is done at the primary school of Sekolah Dasar Negeri Cijujung 03 in the subdistrict of Sukaraja the district of Bogor. It is done in the odd semester in the year of 2014/2015. The study is conducted for 4 months, started from January, February, October and November. The population and sample are taken using the technique of cluster random sampling with 64 students with the composition of 30 male and 34 female students from the class of 5B at Sekolah Dasar Negeri Cijujung 03 at the subdistrict of Sukaraja the district of Bogor.

This study uses quasi experimental method for finding out the effect of applying TGT and STAD on the learning outcome of natural science at VA and VB.

\section{RESULTS AND DISCUSSION}

The data is described in descriptive statistic. The data descriptions are mean, standard of deviation, normality test, homogeneity test, and hypothesis test.

Based on table 1, the class uses Teams Games Tournament having the average score which is higher (7.4) compared to the pre test (5.2). the average score of $N \_$gain at the class using Teams Games Tournament is included in the category of high (1.26). the number of students who achieve the score above the average score increases. It was only one person in the pre test but it becomes 11 people at the post test.

Based on the result of observation at the first cycle, it shows that there is improvement of learning outcome as follows:

Table 2. Pre test, post test, and N_gain at STAD Class

\begin{tabular}{|l|c|c|c|c|}
\hline $\begin{array}{l}\text { The Learning } \\
\text { Outcome } \\
\text { using TGT }\end{array}$ & \multicolumn{2}{|c|}{ Teams Games Tournament (TGT) Class } & \multirow{2}{*}{$\begin{array}{c}\text { The Category } \\
\text { of N_Gain }\end{array}$} \\
\cline { 2 - 4 } & Pretest & Posttest & N_Gain & - \\
\hline $\begin{array}{l}\text { Maximum } \\
\text { Score }\end{array}$ & 6,8 & 7,5 & - & - \\
\hline $\begin{array}{l}\text { Minimum } \\
\text { Score }\end{array}$ & 0,9 & 3,7 & - & High \\
\hline Mean & 4,5 & 5,7 & 1,02 & - \\
\hline Sd & 2,1 & 2,3 & - & - \\
\hline $\begin{array}{l}\text { The number of } \\
\text { students } \\
\text { having higher } \\
\text { score than the } \\
\text { average }\end{array}$ & 10 & 15 & - & \\
\hline
\end{tabular}

Based on the above table, the post test of the class using Student Teams Achievement Division (STAD) has higher average score (5.7) compared to its pre test (4.5). the average score of N_gain the class of Student Teams Achievement Division (STAD) is categorized as high (1.02). the number of students achieving the score above the average was 10 people but at the post test it becomes 15 .

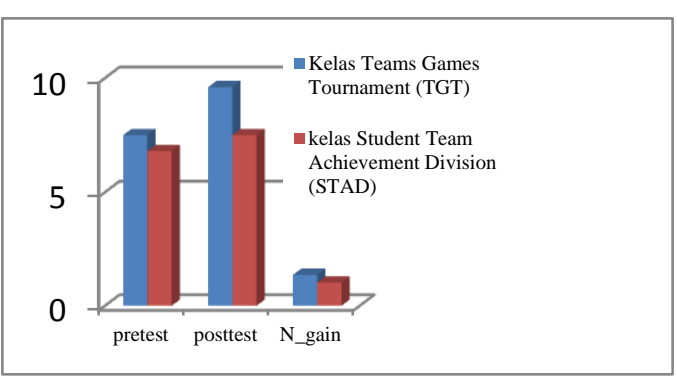

Figure 1. Bar Diagram on class recapitulation of Teams Games Tournment and Teams Games Achievement Division 
Table 3. The Result of Normality and Homogenity Tests, N_Gain and (TGT)

\begin{tabular}{|c|c|c|c|c|}
\hline $\begin{array}{c}\text { Learning } \\
\text { Outcome } \\
\text { using STAD }\end{array}$ & $\begin{array}{l}\text { The Testing } \\
\text { Components }\end{array}$ & Sig. & Interpretation & Notes \\
\hline Pre test & \multirow{3}{*}{ Normality } & 0,704 & Normal & \multirow{3}{*}{$\begin{array}{c}\text { Significance } \\
\text { level of }>\alpha \\
(0,05)\end{array}$} \\
\hline Post test & & 0,199 & Normal & \\
\hline $\mathrm{N}$ gain & & 0.601 & Normal & \\
\hline N_gain & Homogenity & 0.057 & Homogenous & $\begin{array}{c}\text { Significance } \\
\text { Level of }>\alpha \\
(0,05)\end{array}$ \\
\hline
\end{tabular}

Based on table 3 significance (Sig) value is gained. The pre test of Teams Games Tournament class is 0.704. the significance value of Teams Games Tournament class with the projection $>\alpha(0,05)$. The result shows that the pre test gained by Teams Games Tournament class is normally distributed.

The above table 3 shows that the significance value (Sig.) of the post test at Teams Games Tournament class is $0,199>\alpha(0,05)$. The result shows that the post test data gained in Teams Games Tournament is normally distributed.

Based on table 3 it can also be inferred that the significance value (Sig) of the $\mathrm{n}_{\text {ggain }}$ at Teams Games Tournament class is 0.704 . the significance value of the class is $>\alpha(0,05)$. It shows that the N_gain of Teams Games Tournament class is normally distributed. After knowing that the N_gain of Teams Games Tournament class is normally distributed, then the next step is testing the homogeneity of variance from N_gain. Based on table 3, the significance value of homogeneity testing of N_gain $=0.057$. therefore, the significance value $>\alpha(0,05)$, then the N_gain data of (TGT) class is homogenous or having common variance.

Table 4. The Result of Normality Test and Homogenity Test of Pre-test, Post-test and N_gain using STAD

\begin{tabular}{|c|c|c|c|c|}
\hline $\begin{array}{c}\text { Learning } \\
\text { Outcome } \\
\text { using STAD }\end{array}$ & $\begin{array}{l}\text { The Testing } \\
\text { Components }\end{array}$ & Sig. & Interpretation & Notes \\
\hline Pre test & \multirow{3}{*}{ Normality } & 0,407 & Normal & \multirow{3}{*}{$\begin{array}{c}\text { Significance } \\
\text { Value }>\alpha \\
(0,05)\end{array}$} \\
\hline Post test & & 0,851 & Normal & \\
\hline N_gain & & 0.968 & Normal & \\
\hline N_gain & $\begin{array}{c}\text { Homogenit } \\
\mathrm{y}\end{array}$ & 0.057 & Homogenous & $\begin{array}{c}\text { Significance } \\
\text { value }>\alpha \\
(0,05)\end{array}$ \\
\hline
\end{tabular}

Based on table 4 the significance value (Sig). of the pre test at STAD class is 0.407 . The significance value of STAD class $>\alpha(0,05)$. The result shows that the pre test gained by STAD class is normally distributed.

Table 4 shows that the significance value (Sig). of the post test at STAD class is $0.851>\alpha(0.05)$. The result shows that the post test gained from STAD class is normally distributed.

Based on table 4 the significance value (Sig). for the N-gain data at STAD class is known, which is 0.968 . the significance value of the class is $>\alpha(0,05)$. The result shows that the $\mathrm{N}$-gain ata of STAD class is normally distributed. After being known that the the Ngain of STAD class is normally distributed, the next step is testing the homogeneity of the variance from the $\mathrm{N}$-gain data. Based on the table 4.3, the significance value of homogenity testing of $\mathrm{N}$-gain is 0.057 . hence the significance value is $>\alpha(0.05)$, meaning that the N_gain data of STAD class is homogenous or having common variance.

Table 5. The Result of hypothetical test of the natural science subject learning outcome of the classes using TGT and STAD

\begin{tabular}{|c|c|}
\hline Hypothetical Test & Result \\
\hline Ttailed & 0,00 \\
\hline Significance & 0.05 \\
\hline Testing Result & $\mathrm{H}_{\mathrm{a}}$ is accepted because \\
& $0.00<0.05$ \\
\hline
\end{tabular}

NoteK $\mathrm{H}_{\mathrm{a}}$ is accepted because Ttailed $(0.00)<$ significance value $(0.05)$

From the table 4.5 , it is gained that Ttailed value < significance or $0.00<0.05$ or $\mathrm{Ha}$ is accepted. It shows that the learning outcome of natural science subject of the classes using and (STAD) has significant difference. Hence, ot can be inferred that (TGT) and (STAD) classes have cognitive ability which is in common about human digestion materials.

The Improvement of Learning Outcome Using TGT

The score of pre test of Natural Science Subject at Teams Games Tournament class reaches the average of 2. It is because at the pre test, the students at TGT class has not been treated and taught about the tested material. At the post test, the average score becomes 7.4. it is because the students have been taught the material, so they know it already. It causes the learning outcome to be better. Learning outcome is the change of behaviour happened to students after joining a learning process (Saefullah, 2012).

The N_gain result at TGT class is classified into high because in the learning process, they are treated using TGT which is able to provoke the students' learning motivation. The strength of learning process using TGT is the students are learning while palying games. So the post test result of TGT class improves and it is higher than the class using Student Teams Achievement Division. Meanwhile the weakness of TGT is those ehose cognitive is low will be left behind by those who have high cognitive. A good learning process should make the whole students get improvement.

\section{The Improvement of Learning Outcome to Students Using Student Teams Achievement Division}

The pre test score of STAD class has the average of 5. it is the same as those in Student Teams Achievement Division class because they were tested 
before being treated STAD. So it is normal if the average score is still low. Student Teams Achievement Division class improves after getting the treatment into 5.7. It is because the students at STAD class have gained knowledge about the tested material. That is why their average score improves. It is in accordance with Sudjana (2002) who says that the learning outcome of the students means the change of behaviour covering cognitive, affective, and psychomotoric aspects.

However the unique thing is the score of $\mathrm{N}$ gain of TGT class reaches 1.26 which categorizes as high. This is very different from what happens to Student Teams Achievement Division class which reaches 1.02. it is probably because the two classes implement different teaching techniques whuch are TGT which uses games while STAD which presents group work in front of the class.

The Difference of Improvement between Classes Using Teams Games Tournament and Student Teams Achievement Division

After being hypothetical testing, it is gained that the null hypothesis $\left(\mathrm{H}_{0}\right)$ is accepted, which states that there is no difference in result between students who are TGT and STAD to the learning outcome of natural science subject of $5 \mathrm{~A}$ and $5 \mathrm{~B}$.

Wigianti in her undergraduate thesis says that teachers make their performance better when using a particular teaching technique which is suitable for the class condition, like what Slavin (2009) says, “ cooperative learning is a teaching method that does not only make students improve their achievement but also a way to make a fun and pro social condition in the class which support the development of interpersonal and learning effectiveness.

Therefore, the result of hypothesis testing shows that the use of TGT and STAD have different learning outcome to the eaching of natural science subject. It is because Teams Games Tournament TGT is a technique with palying games while learning so it is effective to improve the learning outcome of the students when learning natural science subject. TGT also is able to make the material easy to understand and makes students focused more on the lesson being taught.

\section{CONCLUSION}

Based on hypothesis testing using $t$ test, it can be inferred that The Teaching Technique of Teams Games Tournament with learning model Student Teams Achievement Division is able to improve the Learning Outcome of Natural Science Subject of the fifth grade students at Sekolah Dasar Negeri Cijujung 03 in the sub district of Sukaraja, the district of Bogor.

\section{REFERENCES}

Dimyati. 2006. Belajar dan Pembelajaran. Jakarta: Rineka Cipta.

Isjoni. 2009. Pembelajaran Kooperatif Meningkatkan Kecerdasan Komunikasi Antar Peserta Didik. Yogyakarta: Pustaka Belajar.

Kunandar. 2008. Langkah Mudah Penelitian Tindakan Kelas sebagai Pengembangan Profesi Guru. Jakarta: Rajawali Press.

Rusman. 2011. Model-model Pembelajaran Mengembangkan Profesionalisme Guru. Jakarta: Rajawali Press.

Saefullah. 2012. Psikologi Perkembangan dan Pendidikan. Bandung: CV Pustaka Setia.

Slavin, Robert. 2009. Cooperatitive Learning Teori Riset dan Praktik. Bandung: Nusa Media.

Suprijono, Agus. 2009. Cooperative Learing Teori dan Aplikasi PAIKEM. Yogyakarta: Pustaka Pelajar.

Suchyadi, Y. (2017). Relationship between Work Motivation and Organizational Culture in Enhancing Professional Attitudes of Pakuan University Lecturers, 01(01). Retrieved from https://journal.unpak.ac.id/index.php/jhss/article/vie w/372/296

Trianto. 2010. Mendesain Model Pembalajaran Inovatif- Progresif. Jakarta: Kencana. 